\title{
The effect of particle size of full-fat rapeseed and of multi-carbohydrase enzyme supplementation on nutrient digestibility and performance in broilers
}

\author{
A. Rutkowski, S. Kaczmarek ${ }^{1}$, A. Szczyrkowska and D. Józefiak \\ Poznan University of Life Sciences, Department of Animal Nutrition and Feed Management \\ Wotyńska 33, 60-637 Poznań, Poland
}

(Received 7 February 2012; revised version 27 April 2012; accepted 18 June 2012)

\begin{abstract}
The aim of the study was to investigate the effect of the particle size of full-fat rapeseed and of multi-carbohydrase enzyme supplementation on chicken performance. The experiment was conducted with 480 male broiler chickens, divided into four dietary treatments, 15 replications with 8 birds each. Two basal diets were prepared containing fine-ground (FG) or coarse-ground (CG) rapeseed. Diets were unsupplemented or supplemented with a multi-carbohydrase enzyme preparation. The $\mathrm{CG}$ rapeseed depressed $(\mathrm{P}<0.05)$ body weight gain and feed conversion ratio $(\mathrm{P}<0.05)$ in comparison with FG. Birds consuming diets supplemented with multi-carbohydrase enzymes had a higher feed intake and body weight gain and a better feed conversion ratio during the first 2 weeks of life $(\mathrm{P}<0.05)$. During the first 14 days of life, fine grinding of rapeseed had positive effects on nitrogen retention (55.7 vs $50.8 \%$ ), total tract digestibility of crude fat (70.4 vs $38.9 \%)$, and $\mathrm{AME}_{\mathrm{N}}$ value $(\mathrm{P}<0.05)$. It can be concluded that fine grinding may be used to improve the nutritional value of full-fat rapeseed in broilers.
\end{abstract}

KEY WORDS: full-fat rapeseed, particle size, carbohydrase enzymes, broiler chickens

\section{INTRODUCTION}

Rapeseed production and use in Europe has substantially increased in the past several years and reached over 21 million tons in 2009; in Poland rapeseed production that year came to almost 2.5 million tons (FAOSTAT, 2011). There

\footnotetext{
${ }^{1}$ Corresponding author: e-mail: sebak1@up.poznan.pl
} 
is growing interest within the feed industry in using rapeseed by-products in poultry feeding (Mikulski et al., 2012) and full-fat oilseeds in broiler chicken diets. Full-fat rapeseed (FFRS) is a valuable source of energy and protein for poultry (Gordon et al., 2004; Meng et al., 2006). It has been demonstrated that its feeding value could be affected by incomplete rupture of the seed structure during feed processing (Meng et al., 2006). Nutrient encapsulation by cell walls may not be broken down in the poultry gastrointestinal tract, which can result in poor energy utilization. It has been documented that the use of an appropriate combination of cell wall-degrading enzymes can improve the nutritive value of oilseeds for poultry. Recent research by Meng et al. (2006) demonstrated that supplementation of canola seed-containing diets with a combination of cell walldegrading enzymes was effective in improving feed conversion ratio (FCR), dry matter (DM) and non-starch polysaccharide (NSP) digestibility, and apparent metabolizable energy $\left(\mathrm{AME}_{\mathrm{N}}\right)$ level.

In recent years, a considerable amount of data on the mode of action of carbohydrases in rapeseed diets has been published (Meng and Slominski, 2005; Jia et al., 2008; Assadi et al., 2011), however, there is limited information available about processing of this raw material.

The aim of the present study was to investigate the effect of full-fat rapeseed particle size and multi-carbohydrase supplementation on broiler chicken performance and nutrient digestibility.

\section{MATERIAL AND METHODS}

\section{Experimental diets}

Two basal diets (Table 1) containing fine-ground (FG) or coarse-ground (CG) rapeseed were used in the study. The two particle size distributions were achieved by grinding rapeseed using a Skiold disc mill (Skiold A/S, Denmark) at $0.1 \mathrm{~mm}(\mathrm{FG})$ or 1.5 (CG) disc distance. To determine particle size distribution, samples $(\mathrm{n}=5)$ of ground rapeseed $(15 \mathrm{~g})$ were sieved using a set of sieves of 2.0, 1.6, 1.25, 1.00 and $0.63 \mathrm{~mm}$ (Endecotts, London, UK). The samples were shaken using an Endecotts Test Sieve Shaker for $25 \mathrm{~min}$. Before determination of particle size distribution, ground FFRS samples and sieves were cooled to $-18^{\circ} \mathrm{C}$ to prevent particle agglomeration and fat loss. The mass of recovered sample from each sieve was recorded and expressed as a percentage of the total sample used. The average particle size distribution of coarse and fine rapeseed samples is presented in Table 2. Titanium dioxide $(2 \mathrm{~g} / \mathrm{kg})$ was used as an internal marker to calculate digestibility and to determine $\mathrm{AME}_{\mathrm{N}}$ values. Diets (Table 1) were unsupplemented or supplemented on top with $0.5 \mathrm{~g} / \mathrm{kg}$ enzyme 
preparation (Superzyme OM - Canadian Bio-Systems Inc., Calgary, Canada), which supplied $2100 \mathrm{U}$ cellulase, $300 \mathrm{U}$ mannanase, $37.5 \mathrm{U}$ galactanase, $750 \mathrm{U}$ xylanase, $450 \mathrm{U}$ glucanase, $1875 \mathrm{U}$ amylase and $150 \mathrm{U}$ of protease (according to the producer's declaration) per kg of diet. All birds were fed ad libitum with mash diets: starter from day 1 to 14, grower from day 15 to 35 .

Table 1. Composition $\left(\mathrm{g} \cdot \mathrm{kg}^{-1}\right)$, calculated and analysed nutritional value of the diets

\begin{tabular}{|c|c|c|}
\hline \multirow{2}{*}{ Components } & \multicolumn{2}{|c|}{ Diets, period of feeding } \\
\hline & 1-14 day & $15-35$ day \\
\hline \multicolumn{3}{|l|}{ Ingredients } \\
\hline rapeseed $^{1}$ & 125 & 170 \\
\hline wheat & 517.5 & 563.3 \\
\hline soyabean meal & 316 & 230 \\
\hline monocalcium phosphate & 14 & 10.5 \\
\hline limestone & 5 & 5 \\
\hline $\mathrm{NaCl}$ & 3.5 & 3.6 \\
\hline $\mathrm{NaHCO}_{3}$ & 1 & - \\
\hline L-lysine & 2.5 & 2.3 \\
\hline DL-methionine & 2.5 & 2.3 \\
\hline L-threonine & 1 & 1 \\
\hline mineral-vitamin premix ${ }^{2}$ & 1 & 1 \\
\hline $\mathrm{TiO}_{2}$ & 2 & 2 \\
\hline \multicolumn{3}{|l|}{ Analysed $^{3}$} \\
\hline gross energy, $\mathrm{MJ} \mathrm{kg}^{-1}$ & 18.0 & 18.5 \\
\hline crude protein & 219 & 195 \\
\hline crude fibre & 32 & 31 \\
\hline crude fat & 68 & 82 \\
\hline \multicolumn{3}{|c|}{$\begin{array}{l}\text { canola type, low glucosinolate and low erucic acid; }{ }^{2} \text { mineral and vitamin premix provides per kg } \\
\text { diet: IU: vit. A } 11250 \text {, cholecalciferol } 2500 \text {; mg: vit. E } 80 \text {, menadione } 2.50 \text {, vit. } \mathrm{B}_{12} 0.02 \text {, folic acid } \\
\text { 1.17, choline } 379 \text {, D-pantothenic acid } 12.5 \text {, riboflavin } 7.0 \text {, niacin } 41.67 \text {, thiamin } 2.17 \text {, D-biotin } \\
0.18 \text {, pyridoxine } 4.0 \text {, ethoxyquin } 0.09, \mathrm{Mn} 73, \mathrm{Zn} 55, \mathrm{Fe} 45, \mathrm{Cu} 20, \mathrm{I} 0.62 \text {, Se } 0.3 \text {, salinomycin } \\
60 ;{ }^{3} \mathrm{n}=4\end{array}$} \\
\hline
\end{tabular}

Table 2. Particle size distribution of ground rapeseed used in treatments fine (FG) and coarse ground $(\mathrm{CG})$

\begin{tabular}{lcrr}
\hline \multirow{2}{*}{$\mathrm{mm}$} & \multicolumn{2}{c}{ Particle size distribution, \% total } & \multicolumn{2}{c}{$\mathrm{P}$} \\
\cline { 2 - 3 } & $\mathrm{FG}$ & $\mathrm{CG}$ & 0.002 \\
2.00 & $2.54^{1}$ & 5.0 & $<0.001$ \\
$2.00-1.60$ & 4.04 & 13.6 & $<0.001$ \\
$1.60-1.25$ & 7.82 & 46.7 & 0.079 \\
$1.25-1.00$ & 10.4 & 13.5 & $<0.001$ \\
$1.00-0.63$ & 51.1 & 17.4 & 0.003 \\
$0.63-0.40$ & 24.1 & 3.8 &
\end{tabular}




\section{Bird management and data collection}

The experiment complied with the guidelines of the Local Ethics Commission with respect to experimentation and care of animals under study.

The experiment was conducted with 480 one-day-old male Ross 308 chicks. At arrival, 100 birds were weighed and the average arrival weight of the flock was calculated. The birds were kept in 60 floor pens, 8 cockerels per pen ( 16 birds per $\mathrm{m}^{2}$ ). The room environment was managed according to the standard requirements for broiler chickens. All diets were formulated to be isonitrogenous and isocaloric (Table 1). The chickens were randomly divided into four dietary treatments (15 replications each).

Body weight (BW) and feed intake (FI) were measured weekly, whereas body weight gain (BWG) and feed conversion ratio (FCR) were calculated at the end of the trial. Collection trays were installed in floor pens on day 14 and 35 to allow excreta collection; five excreta samples per treatment were collected. One excreta sample represented one pen ( 8 birds). During one day in the fifth week of the experiment, 10 chickens from each group were sacrificed by cervical dislocation and the ileum was removed. Digesta were flushed from the terminal ileum $(15 \mathrm{~cm}$, adjacent to the ileo-caecal junction) and pooled by pen ( 2 birds/sample) to provide sufficient material for chemical analysis $(n=5)$.

Prior to analysis, digesta and excreta samples were homogenized with the use of a stomacher homogenizer (Interscience, France), then freeze-dried (Christ 1825 Medizinischer Apparatebau Osterode/Harz, Germany) and ground (Retsch, Ultra Centrifugal Mill ZM 200, Haan, Germany).

\section{Analytical methods}

The content of dry matter, crude protein, crude fibre in diets, digesta and excreta were determined according to AOAC (2005). Nitrogen content was analysed by a Kjel Foss Automatic 16210 (A/S N. Foss Electric, Denmark) analyser. Fat content was determined using a Soxtec System HT 1043 Extraction Unit (Foss Tecator, Denmark). Titanium dioxide was estimated according to Short et al. (1996), the samples were prepared according to the procedure proposed by Myers et al. (2004). Gross energy was determined using an adiabatic bomb calorimeter (KL 12Mn, Precyzja-Bit PPHU, Poland) standardized with benzoic acid.

\section{Calculations and statistical analysis}

Ileal and total tract apparent protein and fat digestibilities and the dietary AME value were calculated relating the concentration of $\mathrm{TiO}_{2}$ to the content of the nutrient in question or gross energy in feed or digesta (excreta). Total tract 
$\mathrm{AME}_{\mathrm{N}}$ was corrected to zero nitrogen balance using $34.4 \mathrm{~kJ} \cdot \mathrm{g}^{-1} \mathrm{~N}$ retained (Hill and Anderson, 1958).

Statistical analysis of results was performed using the General Linear Models procedure (GLM) of the $\mathrm{SAS}^{\circledast}$ according to the following general model:

$$
Y i j=\mu+\alpha_{i}+\beta_{j}+(\alpha \beta)_{i j}+\varepsilon_{i j}
$$

where: Yij, - the measured dependent variable; $\mu$ - overall mean; $\alpha_{i}$ - the effect of grinding rapeseed; $\beta_{j}$ - the effect of the enzyme preparation; $(\alpha \beta)_{i j}$ - the interaction between grinding of rapeseed and enzyme preparation; $\varepsilon_{i j}$ - random error.

Means were compared pair-wise using Duncan's multiple range test. Differences between particle size distribution of rapeseed samples and their significance were evaluated by Student's $t$-test. All data are presented as means with pooled standard error of the mean (SEM).

\section{RESULTS}

Comparison of the particle size distributions of coarse with fine-ground rapeseed (Table 2) showed that the proportion of large particles was reduced and that of fine particles, increased after grinding with the disc distance set at $0.1 \mathrm{~mm}$. FG rapeseed was characterized by a lower share of large particles $(>2.0-1.25 \mathrm{~mm})$ than $\mathrm{CG}$ rapeseed $(\mathrm{P}<0.05)$. In FG rapeseed, the content of particles smaller than $1 \mathrm{~mm}$ was $75 \%$, in $\mathrm{CG}, 21 \%(\mathrm{P}<0.05)$.

Performance results are summarized in Table 3. Dietary CG depressed $(\mathrm{P}<0.05)$ the body weight gain $(\mathrm{BWG})$ and feed conversion ratio $(\mathrm{FCR})$ of the broiler chickens in comparison with FG during the starter period (BWG, over

Table 3. Performance of broiler chickens fed diets with rapeseed ground at two different mill settings (FG-0.1 and CG-1.5 mm) and unsupplemented or supplemented with enzyme preparation [body weight gain (BWG) and feed intake(FI) in $\mathrm{g}$ and feed conversion ratio (FCR) in $\mathrm{kg}$ feed $\cdot \mathrm{kg}^{-1} \mathrm{BWG}$

\begin{tabular}{|c|c|c|c|c|c|c|c|c|c|}
\hline \multicolumn{2}{|c|}{ Treatment } & \multicolumn{3}{|c|}{ 1-14 day } & \multicolumn{3}{|c|}{$15-35$ day } & \multicolumn{2}{|c|}{$1-35$ day } \\
\hline Disc distance & enzyme $^{1}$ & BWG & FI & FCR & BWG & FI & FCR & BWG FI & FCR \\
\hline FG & & $339^{a 2}$ & $513^{\mathrm{a}}$ & $1.53^{\mathrm{b}}$ & $1421^{\mathrm{A}}$ & 2491 & $1.76^{\mathrm{b}}$ & $1760^{\mathrm{a}} 3005$ & $1.7 \mathrm{1}^{\mathrm{b}}$ \\
\hline \multirow[t]{3}{*}{ CG } & & $287^{\mathrm{b}}$ & $483^{b}$ & $1.70^{\mathrm{a}}$ & $1374^{\mathrm{B}}$ & 2485 & $1.81^{\mathrm{a}}$ & $1661^{\mathrm{b}} 2968$ & $1.79^{\mathrm{a}}$ \\
\hline & - & $294^{b}$ & $484^{b}$ & $1.68^{\mathrm{a}}$ & 1379 & $2446^{\mathrm{B}}$ & 1.78 & $1663^{b} 2931^{b}$ & 1.76 \\
\hline & + & $333^{\mathrm{a}}$ & $512^{\mathrm{a}}$ & $1.55^{\mathrm{b}}$ & 1426 & $2530^{A}$ & 1.79 & $1760^{\mathrm{a}} 3042^{\mathrm{a}}$ & 1.74 \\
\hline
\end{tabular}

Interaction

$\begin{array}{lllllllllll}\text { disc distance*enzyme } & \text { ns } & 0.023 & \text { ns } & \text { ns } & \text { ns } & \text { ns } & \text { ns } & \text { ns } & \text { ns }\end{array}$

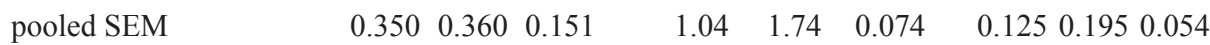

a within main effects means within a column with no common; superscripts differ significantly

$\left.{ }^{\mathrm{a}, \mathrm{b}} \mathrm{P}<0.05\right),{ }^{\mathrm{A}, \mathrm{B}} \mathrm{P}<0.01 ;{ }^{1}$ see Material and Methods; SEM - standard error of the mean; ${ }^{2} \mathrm{n}=30$ 
$50 \mathrm{~g}, \mathrm{FCR}, 0.17 \mathrm{~kg} \cdot \mathrm{kg}^{-1}$ ) and the entire period of the experiment (BWG, over $\left.99 \mathrm{~g}, \mathrm{FCR}, 0.08 \mathrm{~kg} \cdot \mathrm{kg}^{-1}\right)$. The degree of grinding affected feed intake during starter period $(\mathrm{P}<0.05)$ : birds fed $\mathrm{CG}$ rapeseed had a lower feed intake than the chickens fed FG material. In the course of the grower and the entire experimental period, there were no differences in feed intake between dietary treatments. Birds fed diets with FG rapeseed had better FCR than birds fed diets with CG rapeseed. These differences were found during the starter period, grower period, and the entire experiment $(\mathrm{P}<0.05)$.

The use of the enzyme preparation improved performance results (Table $3)$. Birds consuming diets supplemented with the multi-carbohydrase enzyme preparation were characterized by a higher $(\mathrm{P}<0.05)$ BWG (1-14 days, $39 \mathrm{~g}$; 1-35 days, $97 \mathrm{~g})$ and lower FCR $(\mathrm{P}<0.05)$. A significant interaction $(\mathrm{P}=0.023)$ was found between degree of grinding and enzyme supplementation for feed intake on day 14; the addition of the enzymes increased feed intake when FG rapeseed was used but not when $C G$ was fed.

During the first 14 days of the experiment, FG rapeseed had a positive effect on nitrogen retention and total tract digestibility of crude fat in comparison with CG $(\mathrm{P}<0.05)$ (Table 4). The ileal digestibility of crude fat was higher $(\mathrm{P}<0.01)$

Table 4. Nitrogen retention, total tract crude fat digestibility and $\mathrm{AME}_{\mathrm{N}}$ level of diets with full-fat rapeseed ground at two different mill settings (FG - 0.1 and $\mathrm{CG}-1.5 \mathrm{~mm}$ ) and supplemented or not with enzyme preparation

\begin{tabular}{|c|c|c|c|c|c|}
\hline \multicolumn{2}{|c|}{ Treatment } & \multirow{2}{*}{$\begin{array}{c}\begin{array}{c}\text { Nitrogen } \\
\text { retention }\end{array} \\
14^{\text {th }} \mathrm{d} \\
\end{array}$} & \multicolumn{2}{|c|}{$\begin{array}{c}\text { Total tract crude fat } \\
\text { digestibility }\end{array}$} & \multirow{2}{*}{$\frac{\mathrm{AME}_{\mathrm{N}}, \mathrm{MJ} \cdot \mathrm{kg}^{-1}}{14^{\text {th }} \mathrm{d}}$} \\
\hline Disc distance & enzyme $^{1}$ & & $14^{\text {th }} \mathrm{d}$ & $35^{\text {th }} \mathrm{d}$ & \\
\hline FG & & $55.7^{\mathrm{a} 2}$ & $70.4^{\mathrm{a}}$ & $64.0^{\mathrm{a}}$ & $11.8^{\mathrm{a}}$ \\
\hline \multirow[t]{3}{*}{ CG } & & $50.8^{\mathrm{b}}$ & $38.9^{b}$ & $33.3^{\mathrm{b}}$ & $11.1^{\mathrm{b}}$ \\
\hline & - & 51.0 & 53.8 & 45.6 & 11.3 \\
\hline & + & 55.4 & 55.6 & 51.7 & 11.6 \\
\hline \multicolumn{6}{|l|}{ Interaction } \\
\hline \multirow{2}{*}{\multicolumn{2}{|c|}{$\begin{array}{l}\text { discdistance*enzyme } \\
\text { pooled SEM }\end{array}$}} & 0.0256 & ns & ns & ns \\
\hline & & 1.19 & 3.73 & 4.29 & 0.184 \\
\hline
\end{tabular}

when FG rapeseed was used, whereas ileal crude protein digestibility did not differ between FG and CG treatments (Table 5). In 14-day-old chickens, fine grinding of rapeseed had a positive effect $(\mathrm{P}<0.01)$ on the $\mathrm{AME}_{\mathrm{N}}$ value of the diet in comparison with CG rapeseed (Table 4), and this difference accounted for $0.7 \mathrm{MJ}$ per kg diet. The use of dietary enzymes did not affect ileal crude protein or crude fat digestibility during the first 14 days of life. Nitrogen retention was also unaffected by enzyme supplementation. A significant interaction $(\mathrm{P}<0.05)$ between the degree of grinding and enzyme addition (Table 4) was found, however, 
indicating that the effect of enzymes on nitrogen retention differed depending on the degree of grinding. The experimental enzyme improved nitrogen retention in diets containing coarsely ground rapeseed and not in those with finely ground rapeseed.

Table 5. Ileal digestibility of crude fat and crude protein, diets with full-fat rapeseed ground at two different mill settings (FG - 0.1 and CG $-1.5 \mathrm{~mm}$ ) and supplemented or not with enzyme preparation

\begin{tabular}{|c|c|c|c|}
\hline \multicolumn{2}{|c|}{ Treatment } & \multicolumn{2}{|c|}{ Ileal digestibility at $14^{\text {th }} \mathrm{d}, \%$} \\
\hline Disc distance & enzyme $^{1}$ & crude fat & crude protein \\
\hline \multicolumn{4}{|l|}{ Main effects } \\
\hline FG & & $50.8^{\mathrm{a} 2}$ & 59.7 \\
\hline \multirow[t]{3}{*}{ CG } & & $25.9^{\mathrm{b}}$ & 66.7 \\
\hline & - & 36.3 & 61.2 \\
\hline & + & 40.3 & 65.3 \\
\hline \multicolumn{4}{|l|}{ Interaction } \\
\hline disc distance*enzyme & & ns & ns \\
\hline pooled SEM & & 3.48 & 2.09 \\
\hline
\end{tabular}

On day 35 , crude fat total tract digestibility was lower when coarser (CG) material was used $(\mathrm{P}<0.05)$.

\section{DISCUSSION}

Earlier research from this laboratory demonstrated that full-fat rapeseed (FFRS) could be a valuable source of nutrients for poultry. Moreover, applications of multi-carbohydrase preparations improved the nutritional value of this raw material (Józefiak et al., 2010, 2011). Other studies conducted on FFRS nutritive value demonstrated that it could be used in broiler chicken diets at concentrations of up to $100 \mathrm{~g} \cdot \mathrm{kg}^{-1}$ without apparent negative effects on FCR (Gordon et al., 2004). In the present study, fine grinding (FG) improved performance, $\mathrm{AME}_{\mathrm{N}}$ level and digestibility parameters in broiler chickens. The use of fine grinding substantially enhanced crude fat ileal digestibility and total tract digestibility on day 14 . Thus, it may be supposed that the feeding value of coarsely ground rapeseed was affected by incomplete rupture of seeds during processing. It is known that the oil in FFRS is located within numerous cells of the cotyledons, which are surrounded by a thick wall of polysaccharides (Sosulski and Sosulski, 1993). Due to CG treatment, nitrogen retention, fat digestibility, and $\mathrm{AME}_{\mathrm{N}}$ level were lower in comparison with the FG treatment. This may indicate that fat and protein from rapeseed were not fully available for the digestive enzymes of the birds. Noticeable differences 
in crude fat digestibility at the ileum level may partially explain the differences in dietary $\mathrm{AME}_{\mathrm{N}}$ values. Fine grinding possibly released part of the oil and increased the surface area, improving the rate of digestion by the birds' enzymes. Application of heat and mechanical treatments to FFRS proved to be beneficial in improving its nutritional value (Shen et al., 1983; Smulikowska et al., 2006). It is well known that grinding is used to disrupt the cell wall structure of feedstuffs to increase the exposure of nutrients to the digestive enzymes of animals, consequently, to improve bird performance. Nguyen et al. (2003) reported that the performance of birds fed fine-ground rapeseeds was not significantly different from the control treatment (maize and wheat-soya diet). Moreover, Dänicke et al. (1998) reported that roughly ground rapeseed was characterized by lower fat and dry matter digestibility as well as AME value than finely ground material.

In the present study, the incorporation of CG rapeseed into the diet depressed crude fat digestibility in comparison with FC rapeseed. According to Tańska et al. (2008), most Polish rapeseed contains up to $7 \%$ seeds and particles with diameters below $1.6 \mathrm{~mm}$, that of the remaining seeds exceeds $1.6 \mathrm{~mm}$. It could be concluded that the depression of crude fat digestibility was due to the coarsely ruptured seeds rather than to high amounts of intact seeds.

Although the grinding process has positive effects on seed rupture and cell wall disruption, some part of the oil may still be unavailable and may require enzyme supplementation for optimal energy use of FFRS. The nutrient-encapsulating effect of the cell walls may not be overcome by the enzymes produced by poultry because they lack ones able to digest cell-wall polysaccharides. Supplementation of carbohydrases is commonly used to target the cell-wall non-starch polysaccharides of feedstuffs in poultry diets (Choct et al., 1995; Kaczmarek et al., 2009). The nutritional value of FFRS is decreased by the presence of three main antinutritional factors, namely: phytates, glucosinolates and dietary fibre fractions. Moreover, in our recent trials with FFRS (Józefiak et al., 2010, 2011) we also demonstrated that the use of a multicarbohydrase preparation in combination with phytase resulted in the best performance of broilers.

Rapeseed dietary fibre may interfere with nutrient digestion (Asp et al., 1983; Bell, 1993). In the present trial, the use of a multi-carbohydrase preparation did not improve ileal protein digestion and total tract digestibility of crude fat. Nevertheless, performance parameters were positively affected during the first 14 days of life as well as during the entire experiment. Some authors (Mahagna et al., 1995; Gracia et al., 2003; Cowieson et al., 2004) suggested that the use of exogenous enzymes could improve bird performance via limiting endogenous amino acid loss. Cowieson et al. (2004) suggest that endogenous losses decrease by enzymatic degradation of antinutritional factors. Mahagna et al. (1995) and Gracia et al. (2003) proposed that exogenous amylase and protease may supplement endogenous production of enzymes. The above hypotheses seem to 
be supported by the better nitrogen retention after enzyme supplementation on day 14 , as recorded in the present experiment.

\section{CONCLUSIONS}

The present trial demonstrates that fine grinding may be used to improve the nutritional value of full-fat rapeseed in broiler diets.

\section{REFERENCES}

AOAC, 2005. Association of Official Analytical Chemists, Official Methods of Analysis. $18^{\text {th }}$ Edition. Gaithersburg, MA

Asp N.G., Johansson C.G., Hallmer H., Siljestroem M., 1983. Rapid enzymic assay of insoluble and soluble dietary fiber. J. Agr. Food Chem. 31, 476-482

Assadi E., Janmohammadi H., Taghizadeh A., Alijani S., 2011. Nutrient composition of different varieties of full-fat canola seed and nitrogen-corrected true metabolizable energy of full-fat canola seed with or without enzyme addition and thermal processing. J. Appl. Poultry Res. 20, 95-101

Bell J.M., 1993. Factors affecting the nutritional value of canola meal: A review. Can. J. Anim. Sci. 73, 689-697

Choct M., Hughes R.J., Trimble R.P., Angkanaporn K., Annison G., 1995. Non-starch polysaccharidedegrading enzymes increase the performance of broiler chickens fed wheat of low apparent metabolizable energy. J. Nutr. 125, 485-492

Cowieson A.J., Acamovic T., Bedford M.R., 2004. The effects of phytase and phytic acid on the loss of endogenous amino acids and minerals from broiler chickens. Brit. Poultry Sci. 45, 101-108

Dänicke S., Kracht W., Jeroch H., Zachmann R., Heidenreich E., Löwe R., 1998. Effect of different technical treatments of rapeseed on the feed value for broilers and laying hens. Arch. Tierernähr. $51,53-62$

FAOSTAT, 2011. FAOSTAT - database. Accessed January 18, 10

Gordon S.H., Short F., Wilson D.W., Croxall R., 2004. The effect of dietary concentration of rapeseed meal or whole rapeseed on broiler performance and litter quality. In: Procedings of an Spring Meeting of the WPSA UK Branch Papers. Brit. Poultry Sci. 45, Suppl., S21-S22

Gracia M.I., Aranibar M.J., Lazaro R., Medel P., Mateos G.G., 2003. Alpha-amylase supplementation of broiler diets based on corn. Poultry Sci. 82, 436-442

Hill F.W., Anderson D.L., 1958. Comparison of metabolizable energy and productive energy determinations with growing chicks. J. Nutr. 64, 587-603

Jia W., Slominski B.A., Guenter W., Humphreys A., Jones O., 2008. The effect of enzyme supplementation on egg production parameters and omega-3 fatty acid deposition in laying hens fed flaxseed and canola seed. Poultry Sci. 87, 2005-2014

Józefiak D., Ptak A., Kaczmarek S., Maćkowiak P., Engberg R.M., 2011. Exogenous supplementation of carbohydrases lowers serum insulin and cholesterol and improves the nutritive value of fullfat rapeseed in chickens. J. Anim. Feed Sci. 20, 107-117

Józefiak D., Ptak A., Kaczmarek S., Maćkowiak P., Sassek M., Slominski B.A., 2010. Multicarbohydrase and phytase supplementation improves growth performance and liver insulin receptor sensitivity in broiler chickens fed diets containing full-fat rapeseed. Poultry Sci. 89, 1939-1946 
Kaczmarek S., Bochenek M., Józefiak D., Rutkowski A., 2009. Effect of enzyme supplementation of diets based on maize or hominy feed on performance and nutrient digestibility in broilers. J. Anim. Feed Sci. 18, 113-123

Mahagna M., Nir I., Larbier M., Nitsan Y., 1995. Effect of age and exogenous amylase and protease on development of the digestive tract, pancreatic enzyme activities and digestibility of nutrients in young meat-type chicks. Reprod. Nutr. Develop. 35, 201-212

Meng X., Slominski B.A., 2005. Nutritive values of corn, soybean meal, Canola meal, and peas for broiler chickens as affected by a multicarbohydrase preparation of cell wall degrading enzymes. Poultry Sci. 84, 1242-1251

Meng X., Slominski B.A., Campbell L., Guenter W., Jones O., 2006. The use of enzyme technology for improved energy utilization from full-fat oilseeds. Part I: Canola seed. Poultry Sci. 85, $1025-$ 1030

Mikulski D., Jankowski J., Zduńczyk Z., Juśkiewicz J., Slominski B.A., 2012. The effect of different dietary levels of rapeseed meal on growth performance, carcass traits, and meat quality in turkeys. Poultry Sci. 91, 215-223

Myers W.D., Ludden P.A., Nayigihugu V., Hess B.W., 2004. Technical Note: A procedure for the preparation and quantitative analysis of samples for titanium dioxide. J. Anim. Sci. 82, 179183

Nguyen C.V., Biernat M., Smulikowska S., 2003. Influence of feeding full-fat linseed and rapeseed on the morphology of small intestinal mucosa in broiler chickens. J. Anim. Feed Sci. 12, 573582

Shen H., Summers J.D., Leeson S., 1983. The influence of steam pelleting and grinding on the nutritive value of Canola rapeseed for poultry. Anim. Feed Sci. Tech. 8, 303-311

Short F.J., Gorton P., Wiseman J., Boorman K.N., 1996. Determination of titanium dioxide added as an inert marker in chicken digestibility studies. Anim. Feed Sci. Tech. 59, 215-221

Smulikowska S., Mieczkowska A., Czerwiński J., Weremko D., Nguyen C.V., 2006. Effects of exogenous phytase in chickens fed diets with differently processed rapeseed expeller cakes. J. Anim. Feed Sci. 15, 237-252

Sosulski K., Sosulski F.W., 1993. Enzyme-aided vs. two-stage processing of canola: technology, product quality and cost evaluation. J. Amer. Oil Chem. Soc. 70, 825-829

Tańska M., Konopka I., Rotkiewicz D., 2008. Relationships of rapeseed strength properties to seed size, colour and coat fibre composition. J. Agr. Food Chem. 88, 2186-2193 